Jurnal Ilmu Ilmu Agribisnis: Journal of Agribusiness Science, 9(1), Februari 2021

\title{
ANALISIS KINERJA DAN NILAI TAMBAH AGROINDUSTRI TAHU DI KECAMATAN GADINGREJO KABUPATEN PRINGSEWU
}

\author{
(Analysis of Performance and Added Value of Tofu Agroindustry in Gadingrejo Subdistrict \\ Pringsewu Regency)
}

Muhamad Hary Panuju, Teguh Endaryanto dan Lina Marlina

Jurusan Agribisnis, Fakultas Pertanian, Universitas Lampung, Jl. Prof. Dr. Soemantri Brodjonegoro

No.1 Bandar Lampung 35145, e-mail: teguh.endaryanto@fp.unila.ac.id

\begin{abstract}
This research aims to analyze the raw material procurement system based on the elements of raw materials, the performance of production, and added value of the products. The research method used in this research was a case study method on 'Tahu Ibu Lis' tofu agroindustry in Gadingrejo Urban Village, Gadingrejo Subdistrict, Pringsewu Regency. The location of research was determined purposively with the consideration that Tahu Ibu Lis agroindustry was one of agroindustries on the center of tofu production and the biggest production of tofu in Gadingrejo. Tahu Ibu Lis agroindustry had many products, they were tahu pong, tahu kepal, tahu putih, tahu kuning, oncom, and keripik tahu. Research was conducted in Mei - June 2019 and data analysis method used was qualitative and quantitative descriptive analysis and analysis of added value. The study shows that the agroindustry has fulfilled the six components of raw materials procurement, i.e. time, place, price, type, quality, and quantity. The production performance of the agroindustry had not been good because it had not fulfilled the capacity and flexibility components but the rests are good. Tahu Ibu Lis agroindustry was viable because it had positive added value.
\end{abstract}

Key words: added value, performance of production, tofu

\section{PENDAHULUAN}

Lampung merupakan salah satu provinsi di Indonesia. Pembangunan daerah Lampung sedang pada tahap pengerjaan dan pengembangan. Menurut Soekartawi (2010), strategi pembangunan pertanian yang berwawasan agribisnis dan agroindustri pada dasarnya menunjukkan arah bahwa pengembangan agribisnis merupakan suatu upaya yang sangat penting untuk mencapai beberapa tujuan, yaitu menarik dan mendorong munculnya industri baru di sektor pertanian, menciptakan nilai tambah, meningkatkan penerimaan devisa, dan menciptakan lapangan kerja.

Sektor yang cukup berkontribusi terhadap PDRB Provinsi Lampung adalah sektor industri pengolahan dengan nominal sebesar Rp39.618.799 juta atau 17,95 persen (Badan Pusat Statistik 2018). Sektor industri pengolahan ini sangat mendukung pembangunan di negara berkembang. Perkembangan sektor industri pengolahan dapat dicirikan dengan pembangunan pada sektor industri pertanian karena sektor industri dan pertanian saling berkaitan sehingga menghasilkan nilai tambah. Kecamatan Gadingrejo, Kabupaten Pringsewu memiliki beberapa macam agroindustri, diantaranya adalah penggilingan padi, penggilingan kopi, agroindustri gula merah, agroindustri tahu dan agroindustri tempe. Salah satu agroindustri yang banyak berkembang di Kecamatan Gadingrejo adalah agroindustri tahu. Jumlah agroindustri tahu di Kecamatan Gadingrejo pada tahun 2019 berjumlah 13 unit. Salah satu diantara agroindustri tersebut adalah Agroindustri Tahu Ibu Lis yang merupakan agroindustri tahu terbesar di Kecamatan Gadingrejo.

Kegiatan pengadaan bahan baku yang tepat dan sesuai akan mempengaruhi keberlangsungan proses produksi pada agroindustri. Apabila setiap indikator dalam pengadaan bahan baku sudah terpenuhi, maka diharapkan dapat memperlancar kegiatan pengadaan bahan baku serta meminimalisir kemungkinan masalah - masalah yang terkait dengan kegiatan pengadaan bahan baku.

Fluktuasi harga dan ketersediaan bahan baku pada pembuatan tahu akan mempengaruhi jumlah penerimaan dan kelancaran proses produksi usaha tahu. Hal ini dapat mempengaruhi kinerja produksi tahu dalam memenuhi kebutuhan 
konsumen. Kinerja produksi yang baik menghasilkan output yang baik.

Permasalahan- permasalahan tersebut juga berkaitan erat dengan kinerja agroindustri tahu dan pengaruhnya terhadap nilai tambah yang akan diperoleh para pelaku agroindustri. Peningkatan nilai tambah akan diikuti oleh peningkatan pendapatan dan keuntungan agroindustri sehingga diperlukan evaluasi terhadap peningkatan kinerja agroindustri tersebut. Konsep nilai tambah adalah suatu pengembangan nilai yang terjadi karena adanya input fungsional seperti perlakuan dan jasa yang menyebabkan bertambahnya kegunaan dan nilai komoditas selama mengikuti arus komoditas pertanian (Hardjanto 1993).

Nilai tambah tahu pada setiap daerah di Indonesia berbeda- beda. Berdasarkan penelitian sebelumnya dapat dilihat bahwa terjadi variasi nilai tambah. Mengacu penelitian Saputra, Maharani, dan Muwardi (2016), hasil dari nilai produk dikurangi dengan bahan baku dan nilai input lain sehingga diperoleh nilai tambah dari setiap satu kg kedelai sebesar Rp8.184,04. Mengacu penelitian Budiman,Yusri dan Tuty (2014), nilai tambah yang diperoleh dari tahu ukuran kecil adalah sebesar Rp7.607,69/kg, sedangkan nilai tambah yang diperoleh dari tahu ukuran besar adalah sebesar Rp5.578,80/kg. Mengacu penelitian Gunanda dan Elida (2016), nilai tambah yang diperoleh sebesar Rp1.360/kg. Tujuan penelitian ini adalah menganalisis pengadaan bahan baku, kinerja produksi, dan nilai tambah pada agroindustri tahu di Kecamatan Gadingrejo, Kabupaten Pringsewu.

\section{METODE PENELITIAN}

Metode penelitian yang digunakan dalam penelitian ini adalah metode studi kasus. Penelitian dilaksanakan di Agroindustri Tahu Ibu Lis yang terletak di Desa Gadingrejo, Kecamatan Gadingrejo, Kabupaten Pringsewu. Lokasi dipilih secara sengaja (purposive) dengan pertimbangan bahwa Agroindustri Tahu Ibu Lis merupakan agroindustri tahu terbesar di Kecamatan Gadingrejo serta memiliki berbagai macam jenis olahan tahu yang beragam. Waktu pengambilan data dilakukan pada periode produksi pada pertengahan bulan Mei sampai Juni tahun 2019.

Responden pada penelitian ini adalah pemilik agroindustri dan tenaga kerja yang terkait dalam proses produksi tahu. Produk olahan yang dihasilkan di Agroindustri Tahu Ibu Lis diantaranya tahu pong, tahu kepal ukuran besar, tahu kepal ukuran kecil, tahu putih, tahu kuning, tahu sayur, oncom dan keripik tahu dengan berbagai rasa. Data yang digunakan dalam penelitian ini adalah data primer dan data sekunder. Data primer deperoleh dengan menggunakan kuisioner dan pengamatan secara langsung di tempat penelitian. Data sekunder diperoleh dari lembaga - lembaga terkait yang berhubungan dengan objek penelitian, diantaranya data internal Agroindustri Tahu Ibu Lis, UMKM Provinsi Lampung, Badan Pusat Statistik Provinsi Lampung, penelitian terdahulu, jurnal penelitian dan berbagai literatur yang berkaitan dengan topik penelitian.

Metode analisis data yang digunakan adalah analisis deskriptif kuantitatif dan analisis deskriptif kualitatif. Analisis deskriptif kuantitatif digunakan untuk menjawab tujuan penelitian tentang kinerja dan nilai tambah. Analisis kualitatif digunakan untuk menjawab tujuan penelitian pengadaan bahan baku.

Metode analisis yang digunakan pada pengadaan bahan baku adalah deskriptif kualitatif. Metode ini digunakan untuk menganalisis manajemen pengadaan bahan baku berupa pelaksanaan enam tepat pada agroindustri tersebut. Enam tepat pada pengadaan bahan baku tersebut adalah tepat waktu, tepat tempat, tepat harga, tepat jenis, tepat kualitas, dan tepat kuantitas (Assauri 1999).

Metode analisis yang pada kinerja produksi adalah kuantitatif. Metode analisis kinerja produksi di agroindustri tahu dimaksudkan untuk melihat hasil kerja dari agroindustri tahu yang dilihat dari aspek produktivitas tenaga kerja, kapasitas, kualitas, kecepatan pengiriman, dan fleksibilitas (Prasetya dan Fitri 2009).

Produktivitas tenaga kerja dihitung dari unit yang diproduksi (output) dengan masukan yang digunakan (tenaga kerja) yang dirumuskan sebagai berikut (Prasetya dan Fitri 2009) :

Produktivitas $=\frac{\text { Unit yang diproduksi }(\mathrm{kg})}{\text { Input } \mathrm{TK}(\mathrm{HOK})}$.

Dengan ketentuan:

1. Jika produktivitas $>7,2 \mathrm{~kg}$ tahu, maka kinerja agroindustri tersebut sudah baik.

2. Jika produktivitas $<7,2 \mathrm{~kg}$ tahu, maka kinerja agroindustri tersebut kurang baik.

Kapasitas yaitu suatu ukuran yang menyangkut kemampuan output dari suatu proses. Kapasitas 
agroindustri diperoleh dari nilai actual output yaitu output berupa tahu yang diproduksi dengan satuan $\mathrm{kg}$ dibagi dengan design capacity. Kapasitas agroindustri dapat dirumuskan sebagai berikut :

$$
\text { Capacity Utilization }=\frac{\text { Actual Output }(\mathrm{kg})}{\text { Design Capacity }(\mathrm{kg})} \ldots \ldots . .(2)
$$

\section{Keterangan :}

Actual Output = Output yang diproduksi $(\mathrm{kg})$ Design Capacity = Kapasitas memproduksi (kg)

Menurut Render dan Heizer (2001) dalam penelitian Sari, Zakaria, dan Affandi (2015) :

1. Jika kapasitas >0,5 atau 50 persen, maka agroindustri telah berproduksi secara baik;

2. Jika kapasitas $<0,5$ atau 50 persen, maka agroindustri berproduksi kurang baik.

Kualitas proses produksi pada umumnya diukur dengan tingkat ketidaksesuaian dari produk yang dihasilkan. Kualitas tahu dapat dinilai dengan menggunakan parameter terhadap sifat yang dapat dilihat, misalnya warna putih tidak kuning, kering tidak berlendir, tidak berbau dan tekstur yang baik.

Kecepatan pengiriman terbagi menjadi dua ukuran dimensi. Dimensi pertama yaitu jumlah waktu antara produk ketika dipesan untuk dikirimkan ke pelanggan. Dimensi kedua adalah ketepatan waktu dalam pengiriman bahan baku setelah pemesanan.

Fleksibilitas yaitu mengukur bagaimana proses transformasi menjadi lebih baik. Terdapat tiga dimensi dari fleksibilitas, pertama bentuk dari fleksibel dilihat dari kecepatan proses transformasi kedelai menjadi tahu. Kedua adalah kemampuan bereaksi untuk berubah dalam volume. Ketiga adalah kemampuan agroindustri dalam mengubah kedelai menjadi produk selain tahu.

Kecepatan proses adalah perbandingan nyata melalui waktu yang diambil dari produk untuk

Tabel 1. Karakteristik pekerja pada Agroindustri Tahu Ibu Lis

\begin{tabular}{ccccccccc}
\hline \multirow{2}{*}{$\begin{array}{c}\text { Kelompok Umur } \\
\text { (Tahun) }\end{array}$} & \multicolumn{2}{c}{ Jenis Kelamin } & \multicolumn{4}{c}{ Pendidikan Terakhir } & \multirow{2}{*}{ Jumlah } & $\begin{array}{c}\text { Persentase } \\
(\%)\end{array}$ \\
\cline { 2 - 7 } & Laki- laki & Perempuan & Tidak SD & SD & SMP & SMA & & 66,67 \\
\hline $19-31$ & 7 & 1 & 0 & 3 & 4 & 1 & 8 & 6 \\
$32-44$ & 0 & 4 & 1 & 1 & 1 & 1 & 4 & 33,33 \\
\hline Jumlah & 7 & 5 & 1 & 4 & 5 & 2 & 12 & 100,00 \\
\hline
\end{tabular}

melewati proses dibagi dengan nilai tambah waktu yang dibutuhkan untuk melengkapi produk atau jasa. Kecepatan proses dilihat dari berapa lama waktu yang diperlukan dari proses datangnya kedelai sampai menghasilkan tahu.

Metode yang selanjutnya adalah mengenai besarnya nilai tambah dari agroindustri tahu adalah menghitung nilai tambah yang dihasilkan pada proses pengolahan kedelai menjadi tahu pada agroindustri tahu dapat dihitung dengan menggunakan metode Hayami. Menurut Hayami et al. (1987), nilai tambah adalah pertambahan nilai suatu komoditas karena adanya perlakuan yang diberikan pada komoditas yang bersangkutan.

\section{HASIL DAN PEMBAHASAN}

\section{Karakteristik Agroindustri}

Pemilik dan pekerja di Agroindustri Tahu Ibu Lis adalah informan dalam penelitian karena dianggap mengetahui secara jelas tentang kegiatan pada agroindustri. Karakteristik pekerja dan pemilik berbeda-beda baik dari segi umur, pendidikan terakhir, dan jenis kelamin. Agroindustri ini memiliki 12 pekerja dengan beberapa bidang pekerjaan yang berbeda antara lain pengolahan tahu, penggoreng tahu, pengepalan tahu, pengemasan tahu dan pembuatan oncom. Keadaan umur pekerja dapat dilihat pada Tabel 1. Semua pekerja dalam kisaran umur 19 - 44 tahun dan termasuk usia produktif. Kisaran umur produktif adalah 15 - 65 tahun (Mantra 2004).

Berdasarkan Tabel 1, jumlah pekerja terbanyak yaitu pekerja laki-laki sebanyak tujuh orang dan pekerja perempuan sebanyak lima orang. Tingkat pendidikan terakhir pekerja terbanyak adalah SMP yaitu sebanyak empat orang pekerja laki-laki dan satu orang pekerja perempuan. Pemilik agroindustri adalah Ibu Sri Lestari berusia 42 tahun, pendidikan terakhir adalah SMA dengan pengalaman berusaha sejak tahun 2004. 
Tabel 2. Kapasitas pada Agroindustri Tahu Ibu Lis

\begin{tabular}{lccc}
\hline \multicolumn{1}{c}{ Agroindustri } & $\begin{array}{c}\text { Output } \\
(\mathrm{kg})\end{array}$ & $\begin{array}{c}\text { Output } \\
\text { maks }(\mathrm{kg})\end{array}$ & $\begin{array}{c}\text { Kapasitas } \\
(\mathrm{kg})\end{array}$ \\
\hline Tahu Pong & 6.566 & 7.500 & 0,88 \\
Tahu Kepal & & & \\
Besar & 3.920 & 6.000 & 0,65 \\
Tahu Putih & 4.377 & 6.000 & 0,73 \\
Tahu Kepal & & & \\
Kecil & 4.764 & 6.00 & 0,79 \\
Tahu Asin & 1.089 & 4.500 & 0,36 \\
Tahu Kuning & 1.400 & 4.500 & 0,31 \\
Tahu Sayur & 1.456 & 4.500 & 0,32 \\
Oncom & 11.668 & 12.000 & 0,97 \\
Keripik Tahu & 10 & 25 & 0,40 \\
\hline
\end{tabular}

\section{Pengadaan Bahan Baku}

\section{1) Tepat Waktu}

Agroindustri mendapatkan bahan baku dari supplier yang mengirim bahan baku kedelai dari Kecamatan Pringsewu. Supplier akan datang ke tempat agroindustri setelah 1-2 hari pemesanan. Bahan baku di Agroindustri Tahu Ibu Lis biasanya habis setelah 3-4 minggu setelah pemesanan. Berdasarkan hal tersebut, waktu yang digunakan sudah tepat karena supplier datang cepat setelah pemesanan.

\section{2) Tepat Tempat}

Komponen tempat dalam pengadaan bahan baku ini menjelaskan bagaimana keadaan tempat untuk penyediaan bahan baku kedelai dalam pembuatan tahu pada Agroindustri Tahu Ibu Lis. Tempat pada komponen pengadaan bahan baku ini disesuaikan dengan jarak antara supplier dengan agroindustri. Kedelai dikirim supplier dari Pasar Pringsewu yang berjarak kurang lebih $12 \mathrm{~km}$ dengan waktu tempuh 30 menit dari lokasi agroindustri. Berdasarkan hal tersebut, tempat pengadaan bahan baku sudah tepat karena jarak antara supplier dengan agroindustri cukup dekat dengan waktu tempuh yang cepat.

Tabel 3. Fleksibilitas Agroindustri Tahu Ibu Lis

\begin{tabular}{lccc}
\hline Agroindustri & $\begin{array}{c}\text { Jumlah } \\
\text { waktu } \\
\text { produk } \\
\text { si (hari) }\end{array}$ & $\begin{array}{c}\text { Produk } \\
10.000 \\
\text { kedelai } \\
(\mathrm{kg})\end{array}$ & $\begin{array}{c}\text { Produk olahan } \\
\text { lain }\end{array}$ \\
\hline Tahu Pong & 1 & 11.587 & $\begin{array}{c}\text { Oncom, } \\
\text { Keripik }\end{array}$ \\
Tahu Kepal Besar & 1 & 34.473 & Oncom \\
Tahu Putih & 1 & 31.333 & Oncom \\
Tahu Kepal Kecil & 1 & 41.842 & Oncom \\
Tahu Asin & 1 & 15.652 & Oncom \\
Tahu Kuning & 1 & 52.222 & Oncom \\
Tahu Sayur & 1 & 28.823 & Oncom \\
\hline
\end{tabular}

\section{3) Tepat Harga}

Harga kedelai yang dikeluarkan untuk membeli bahan baku kedelai pada waktu penelitian ini di tahun 2019 adalah Rp7.500/kg, hal ini termasuk dalam kisaran harapan harga bahan baku yaitu berkisar antara Rp7.000/kg - Rp8.000/kg. Berdasarkan kegiatan pengadaan bahan baku pada komponen harga bahan baku kedelai pada Agroindustri Tahu Ibu Lis sudah tepat karena harga untuk membeli kedelai termasuk dalam kisaran harapan harga bahan baku.

\section{4) Tepat Jenis}

Terdapat dua jenis bahan baku kedelai yang dapat digunakan pada agroindustri tahu diantaranya adalah bahan baku lokal dan bahan baku. Agroindustri Tahu Ibu Lis menggunakan bahan baku impor yang berasal dari Amerika karena selain harganya lebih murah, kualitas kedelai impor juga lebih baik dan cocok untuk memproduksi tahu. Berdasarkan kegiatan pengadaan bahan baku ini, Agroindustri Tahu Ibu Lis sudah tepat.

\section{5) Tepat Kualitas}

Berdasarkan SNI (1995), kriteria kualitas kedelai yang baik dapat diketahui dari berbagai hal, diantaranya adalah berbentuk bulat, berwarna cokelat kekuningan dan bersih. Kualitas bahan baku yang baik akan menghasilkan produk tahu yang baik. Hasil penelitian ini menunjukkan bahwa komponen kualitas pengadaaan bahan baku di Agroindustri Tahu Ibu Lis sudah tepat karena kualitas kedelai dari supplier secara keseluruhan berbentuk bulat, berwarna cokelat kekuningan dan bersih.

\section{6) Tepat Kuantitas}

Sistem pembelian bahan baku di agroindustri dengan cara pemesanan melalui supplier. Agroindustri biasanya membeli bahan baku sebanyak 7 - 10 ton dengan penggunaan bahan baku kurang lebih $300 \mathrm{~kg} / \mathrm{hari}$ sedangkan sisanya akan disimpan di gudang. Berdasarkan hal tersebut, kuantitas bahan baku di Agroindustri Tahu Ibu Lis sudah tepat.

Berdasarkan hasil penelitian yang telah dilakukan, dapat diketahui bahwa seluruh komponen pengadaan bahan baku sudah tepat. Penelitian ini sejalan dengan hasil penelitian Shafira, Lestari, dan Affandi (2018) yang menyatakan bahwa pengadaan bahan baku pada Agroindustri Tahu SJ, Agroindustri Tahu SY, dan Agroindustri Tahu SD sudah tepat. 
Jurnal Ilmu Ilmu Agribisnis: Journal of Agribusiness Science, 9(1), Februari 2021

Tabel 4. Nilai Tambah produk olahan pada Agroindustri Tahu Ibu Lis

\begin{tabular}{|c|c|c|c|c|c|c|c|c|c|c|}
\hline Variabel & Nilai & $\begin{array}{l}\text { Tahu } \\
\text { Pong }\end{array}$ & $\begin{array}{l}\text { Kepal } \\
\text { Besar }\end{array}$ & $\begin{array}{l}\text { Tahu } \\
\text { Putih }\end{array}$ & $\begin{array}{l}\text { Kepal } \\
\text { Kecil }\end{array}$ & $\begin{array}{l}\text { Tahu } \\
\text { Asin }\end{array}$ & $\begin{array}{c}\text { Tahu } \\
\text { Kuning }\end{array}$ & $\begin{array}{l}\text { Tahu } \\
\text { Sayur }\end{array}$ & Oncom & Keripik \\
\hline \multicolumn{11}{|c|}{ Output, Input dan Harga } \\
\hline $\begin{array}{l}\text { Output }(\mathrm{Kg} / \\
\text { Prod) }\end{array}$ & A & 218,85 & 130,65 & 145,89 & 158,79 & 36,29 & 46,66 & 48,52 & 388,93 & 10,00 \\
\hline $\begin{array}{l}\text { Bahan Baku } \\
\text { (Kg/Prod) }\end{array}$ & $\mathrm{B}$ & 188,67 & 37,92 & 45,42 & 37,50 & 23,33 & 9,00 & 17,33 & 251,42 & 40,00 \\
\hline TK (HOK/Prod) & $\mathrm{C}$ & 4,43 & 1,84 & 0,72 & 2,31 & 0,95 & 0,34 & 0,40 & 2,00 & 0,00 \\
\hline Faktor Konversi & $\mathrm{D}=\mathrm{A} / \mathrm{B}$ & 1,16 & 3,45 & 3,21 & 4,23 & 1,56 & 5,18 & 2,80 & 1,55 & 0,25 \\
\hline Koefisien TK & $\mathrm{E}=\mathrm{C} / \mathrm{B}$ & 0,02 & 0,049 & 0,016 & 0,062 & 0,041 & 0,038 & 0,023 & 0,008 & 0,000 \\
\hline $\begin{array}{l}\text { Harga Output } \\
(\mathrm{Rp} / \mathrm{Kg})\end{array}$ & $\mathrm{F}$ & 17.241 & 7.429 & 5.051 & 7.663 & 22.222 & 6.250 & 6.944 & 3.324 & 100.000 \\
\hline $\begin{array}{l}\text { Upah Rata-rata } \\
\text { TK (Rp/HOK) }\end{array}$ & G & 50.000 & 50.000 & 50.000 & 50.000 & 50.000 & 50.000 & 50.000 & 50.000 & 50.000 \\
\hline \multicolumn{11}{|c|}{ Pendapatan dan Nilai Tambah } \\
\hline $\begin{array}{l}\text { Harga Bahan } \\
\text { Baku (Rp/Kg) }\end{array}$ & $\mathrm{H}$ & 7.500 & 7.500 & 7.500 & 7.500 & 7.500 & 7.500 & 7.500 & 0 & 0 \\
\hline $\begin{array}{l}\text { Sumbangan Input } \\
\text { Lain }(\mathrm{Rp} / \mathrm{Kg})\end{array}$ & I & $2.272,83$ & $1.979,89$ & $1.617,36$ & $3.228,67$ & $4.401,35$ & $3.863,41$ & $3.335,88$ & 298,73 & 275,99 \\
\hline Nilai Output & $\mathrm{J}=\mathrm{D} \times \mathrm{F}$ & $20.000,00$ & $25.600,00$ & $16.224,00$ & $32.448,00$ & $34.560,00$ & $32.400,00$ & $19.440,00$ & $5.142,86$ & $25.000,00$ \\
\hline a. Nilai Tambah & $\mathrm{K}=\mathrm{J}-\mathrm{I}-\mathrm{H}$ & $10.227,58$ & $16.120,11$ & $7.106,64$ & $21.719,33$ & $22.658,65$ & $21.036,59$ & $8.604,12$ & $4.844,12$ & $24.724,01$ \\
\hline b. Rasio Nilai & $\mathrm{L}=(\mathrm{K} / \mathrm{J})$ & 51,16 & 62,97 & 43,80 & 66,94 & 65,56 & 64,93 & 44,26 & 94,19 & 98,90 \\
\hline Tambah & x $100 \%$ & & & & & & & & & \\
\hline a. Imbalan TK & $\begin{array}{l}M=E X \\
G\end{array}$ & $1.173,47$ & $2.428,15$ & 797,16 & $3.077,68$ & $2.207,76$ & $1.901,02$ & $1.140,61$ & 397,75 & 18,15 \\
\hline b. Bagian TK & $\begin{array}{l}\mathrm{N}= \\
(\mathrm{M} / \mathrm{K}) \mathrm{x} \\
100 \%\end{array}$ & 11,47 & 15,06 & 11,22 & 14,17 & 8,95 & 9,04 & 13,26 & 8,21 & 0,07 \\
\hline a. Keuntungan & $\begin{array}{l}\mathrm{O}=\mathrm{K}- \\
\mathrm{M}\end{array}$ & $9.053,70$ & $13.691,96$ & $6.309,48$ & $18.641,65$ & $20.630,89$ & $19.135,57$ & $7.463,51$ & $4.446,38$ & $24.705,86$ \\
\hline $\begin{array}{l}\text { b. Tingkat } \\
\text { Keutungan }\end{array}$ & $\begin{array}{l}P= \\
(\mathrm{O} / \mathrm{K}) \mathrm{x} \\
100 \%\end{array}$ & 88,53 & 84,94 & 88,78 & 85,83 & 91,05 & 90,96 & 86,74 & 91,79 & 99,93 \\
\hline \multicolumn{11}{|c|}{ Balas Jasa untuk Produksi } \\
\hline Margin & $\mathrm{Q}=\mathrm{J}-\mathrm{H}$ & $12.500,00$ & $18.100,00$ & $8.724,00$ & $24.948,00$ & $27.060,00$ & $24.900,00$ & $11.940,00$ & $5.142,86$ & $25.000,00$ \\
\hline a. Keuntungan & $\begin{array}{l}\mathrm{R}=\mathrm{O} / \mathrm{Q} \\
\mathrm{x} 100 \%\end{array}$ & 72,43 & 75,65 & 72,32 & 74,72 & 76,24 & 76,85 & 62,51 & 86,46 & 98,82 \\
\hline b. Tenaga Kerja & $\begin{array}{l}\mathrm{S}=\mathrm{M} / \mathrm{Q} \\
\mathrm{x} 100 \%\end{array}$ & 11,47 & 15,06 & 11,22 & 14,17 & 8,95 & 9,04 & 13,26 & 8,21 & 0,07 \\
\hline c. Input Lain & $\begin{array}{l}\mathrm{T}=\mathrm{I} / \mathrm{Q} \mathrm{x} \\
100 \%\end{array}$ & 18,18 & 10,94 & 18,54 & 12,94 & 16,27 & 15,52 & 27,94 & 5,81 & 1,10 \\
\hline
\end{tabular}

\section{Kinerja Produksi}

1) Produktivitas

Rata-rata produktivitas tenaga kerja agroindustri pada jenis tahu pong antara output terhadap tenaga kerja adalah sebesar 54,45 kg/HOK. Produktivitas tenaga kerja pada jenis tahu kepal besar berdasarkan perhitungan rata- rata antara output terhadap tenaga kerja adalah sebesar 88,70 $\mathrm{kg} / \mathrm{HOK}$. Produktivitas tenaga kerja pada jenis tahu putih berdasarkan perhitungan rata- rata antara output terhadap tenaga kerja adalah sebesar $209,31 \mathrm{~kg} / \mathrm{HOK}$.

Rata- rata produktivitas tenaga kerja agroindustri pada jenis tahu kepal kecil antara output terhadap tenaga kerja adalah sebesar $86,00 \mathrm{~kg} / \mathrm{HOK}$. Ratarata produktivitas tenaga kerja pada jenis tahu asin antara output terhadap tenaga kerja adalah sebesar $42,25 \mathrm{~kg} / \mathrm{HOK}$. Rata- rata produktivitas tenaga kerja pada jenis tahu kuning antara output terhadap tenaga kerja adalah sebesar $150,20 \mathrm{~kg} / \mathrm{HOK}$.
Produktivitas tenaga kerja agroindustri pada jenis tahu sayur berdasarkan perhitungan rata- rata antara output terhadap tenaga kerja adalah sebesar $135,18 \mathrm{~kg} / \mathrm{HOK}$. Produktivitas tenaga kerja pada produk oncom berdasarkan perhitungan rata- rata antara output terhadap tenaga kerja adalah sebesar $170,94 \mathrm{~kg} / \mathrm{HOK}$. Produktivitas tenaga kerja pada keripik tahu berdasarkan perhitungan rata- rata antara output terhadap tenaga kerja sebesar 281,63 $\mathrm{kg} / \mathrm{HOK}$.

Standar nilai produktivitas tenaga kerja menurut Render dan Heizer (2001) adalah 7,2 kg/HOK. Jika produktivitas $\geq 7,2 \mathrm{~kg} / \mathrm{HOK}$, maka kinerja agroindustri tersebut sudah baik. Berdasarkan hasil perhitungan, diketahui bahwa nilai produktivitas semua produk di Agroindustri Tahu telah melebihi standar nilai produktivitas tenaga kerja, maka produktivitas Agroindustri Tahu Ibu Lis sudah baik. 


\section{2) Kapasitas}

Berdasarkan Tabel 2, Agroindustri Tahu Ibu Lis sudah berproduksi dengan baik untuk semua jenis produk karena nilai kapasitas melebihi nilai 0,5 atau 50 persen, kecuali pada produksi tahu asin, tahu kuning, tahu sayur, dan keripik tahu yang memiliki kapasitas produksi yang kurang baik karena nilai kapasitas kurang dari 50 persen. Produk keripik tahu memiliki kapasitas produksi yang kurang baik disebabkan oleh penjualan yang tidak menentu, selain itu produk tahu kuning juga merupakan jenis produk yang baru dijalankan agroindustri tersebut sehingga permintaannya masih sedikit.

Produk oncom memiliki kapasitas produksi terbesar, hal ini disebabkan bahan baku oncom berasal dari sisa semua produk tahu yang memungkinkan untuk memproduksi sangat besar. Sebanyak lebih dari 50 persen produk olahan di Agroindustri Tahu Ibu Lis kapasitas produksinya telah baik. Hasil penelitian ini sejalan dengan penelitian Sagala, Affandi, dan Ibnu. (2013) nilai rata-rata kapasitas agroindustri kelanting adalah sebesar 0,92 atau 92 persen.

\section{3) Kualitas}

Kualitas produk yang dihasilkan mempengaruhi keberlangsungan suatu agroindustri. Kualitas dari proses pada umumnya diukur dengan tingkat ketidaksesuaian dari produk yang dihasilkan. Tahu yang memiliki kualitas yang baik dapat dilihat dari aroma yang berbau kedelai, tekstur padat, dan tidak berlendir. Berdasarkan hasil penelitian, produk tahu di Agroindustri Tahu Ibu Lis secara keseluruhan beraroma kedelai, memiliki tekstur yang padat, serta tidak berlendir sehingga kualitas tahu sudah baik.

\section{4) Kecepatan Pengiriman}

Kecepatan pengiriman diukur berdasarkan dua ukuran dimensi, pertama jumlah waktu antara produk ketika dipesan untuk dikirimkan kepada pelanggan, dan kedua adalah ketepatan dalam waktu pengiriman. Bahan baku didapat dari supplier dan akan datang 1 - 2 hari setelah pemesanan. Bahan baku yang didapat sebanyak 7 - 10 ton dan dapat habis selama kurang lebih satu bulan. Frekuensi proses produksi pada Agroindustri Tahu Lis dilakukan setiap hari. Hasil produksi tahu dijual sendiri oleh pemilik ke pasar dan untuk keripik tahu dijual di lokasi agroindustri dan dipasarkan melalui media sosial.

Pemasaran yang dilakukan oleh Agroindustri Tahu Ibu Lis dilakukan setiap hari dengan menggunakan mobil bak milik agroindustri tersebut. Produk tahu yang diproduksi akan dijual ke dua lokasi pasar, yaitu Pasar Pringsewu dan Pasar Gadingrejo. Jarak yang ditempuh dari agroindustri menuju Pasar Gadingrejo satu km dengan waktu tempuh lima menit, sedangkan untuk menuju ke Pasar Pringsewu yang berjarak $12 \mathrm{~km}$ membutuhkan waktu tempuh 30 menit. Berdasarkan hal tersebut, waktu pengiriman produk tahu pada Agroindustri Tahu Ibu Lis sudah baik, karena jarak tempuh dari agroindustri ke lokasi pemasaran cukup dekat.

\section{5) Fleksibilitas}

Terdapat tiga dimensi dari fleksibilitas, pertama bentuk dari fleksibel dilihat dari waktu untuk mendatangkan bahan baku. Waktu yang dibutuhkan dari datangnya bahan baku sampai menjadi tahu berkisar selama satu hari. Dimensi yang kedua adalah kemampuan bereaksi untuk berubah dalam volume, yaitu bagaimana kemampuan kedelai untuk menghasilkan tahu. Dimensi yang ketiga adalah kemampuan dari proses produksi yang lebih dari satu produk secara serempak atau kemampuan agroindustri tahu dalam mengubah kedelai menjadi produk selain tahu.

Apabila ketiga dimensi dalam fleksibilitas terpenuhi, maka fleksibilitas pada aroindustri sudah baik. Berdasarkan Tabel 3, dapat disimpulkan bahwa dari aspek fleksibilitas pada Agroindustri Tahu Ibu Lis sudah optimal karena setiap dimensi pengukuran sudah memenuhi kriteria.

\section{6) Kecepatan Proses}

Kecepatan proses adalah perbandingan nyata melalui waktu yang diambil dari produk untuk melewati proses yang dibagi dengan nilai tambah waktu yang dibutuhkan untuk melengkapi produk atau jasa. Kecepatan proses dilihat dari lama waktu yang dari proses datangnya kedelai sampai menghasilkan tahu. Waktu yang dibutuhkan dari datangnya bahan baku dan diproses menjadi tahu berkisar selama satu hari. Proses pengolahan tahu pada agroindustri tergolong cepat dan tidak terdapat kendala dalam proses pengolahannya, sehingga kecepatan proses pada Agroindustri Tahu Ibu Lis sudah tepat. 
Tabel 5. Alokasi join cost dengan metode nilai jual relatif

\begin{tabular}{|c|c|c|c|c|c|c|c|c|c|}
\hline Nama Alat & $\begin{array}{l}\text { Tahu } \\
\text { Pong } \\
(\%) \\
\end{array}$ & $\begin{array}{l}\text { Tahu } \\
\text { Kepal } \\
\text { Besar }(\%)\end{array}$ & $\begin{array}{l}\text { Tahu } \\
\text { Putih } \\
(\%)\end{array}$ & $\begin{array}{l}\text { Tahu } \\
\text { Kepal } \\
\text { Kecil }(\%)\end{array}$ & $\begin{array}{l}\text { Tahu } \\
\text { Asin } \\
(\%)\end{array}$ & $\begin{array}{l}\text { Tahu } \\
\text { Kuning } \\
(\%)\end{array}$ & $\begin{array}{l}\text { Tahu } \\
\text { Sayur } \\
(\%)\end{array}$ & $\begin{array}{l}\text { Oncom } \\
(\%)\end{array}$ & $\begin{array}{l}\text { Keripik } \\
(\%)\end{array}$ \\
\hline Diesel & 46,40 & 11,94 & 9,06 & 14,96 & 9,92 & 3,59 & 4,14 & - & - \\
\hline Drum Uap & 46,40 & 11,94 & 9,06 & 14,96 & 9,92 & 3,59 & 4,14 & - & - \\
\hline Cetakan & 46,40 & 11,94 & 9,06 & 14,96 & 9,92 & 3,59 & 4,14 & - & - \\
\hline Penyaring Tahu A & 46,40 & 11,94 & 9,06 & 14,96 & 9,92 & 3,59 & 4,14 & - & - \\
\hline Penyaring Tahu B & 46,40 & 11,94 & 9,06 & 14,96 & 9,92 & 3,59 & 4,14 & - & - \\
\hline Blower & 39,89 & 10,26 & 7,79 & 12,86 & 8,53 & 3,08 & 3,56 & 13,67 & 0,35 \\
\hline Ember & 46,40 & 11,94 & 9,06 & 14,96 & 9,92 & 3,59 & 4,14 & - & - \\
\hline Giling Kedelai & 46,40 & 11,94 & 9,06 & 14,96 & 9,92 & 3,59 & 4,14 & - & - \\
\hline Pisau & 40,03 & 10,30 & 7,82 & 12,91 & 8,56 & 3,09 & 3,57 & 13,72 & - \\
\hline Kuali & 76,23 & - & - & - & 16,29 & - & 6,81 & - & 0,67 \\
\hline Tirisan & 76,23 & - & - & - & 16,29 & - & 6,81 & - & 0,67 \\
\hline Panci Rebus & - & - & - & - & - & 100,00 & - & - & - \\
\hline Keranjang & 46,40 & 11,94 & 9,06 & 14,96 & 9,92 & 3,59 & 4,14 & - & - \\
\hline Meja Alas Tahu & 46,40 & 11,94 & 9,06 & 14,96 & 9,92 & 3,59 & 4,14 & - & - \\
\hline Tempat Oncom & - & - & - & - & - & - & - & 100,00 & - \\
\hline Alat Peras Oncom & - & - & - & - & - & - & - & 100,00 & - \\
\hline Panci Kukus & - & - & - & - & - & - & - & 100,00 & - \\
\hline
\end{tabular}

\section{Analisis Nilai Tambah Agroindustri Tahu}

Analisis nilai tambah yang dilakukan pada agroindustri adalah analisis rata-rata dalam kurun waktu satu bulan yaitu pada pertengahan bulan Mei sampai pertengahan bulan Juni 2019. Peralatan di agroindustri digunakan secara bersama- sama, oleh sebab itu dilakukan perhitungan alokasi join cost dengan metode nilai jual relatif, kemudian alokasi join cost dikalikan dengan biaya penyusutan dan dimasukkan pada Tabel 4. Perhitungan alokasi join cost untuk penggunaan peralatan dapat dilihat pada Tabel 5.

Penggunaan tenaga kerja terbesar pada agroindustri tersebut adalah pada produk tahu pong yaitu sebesar 4,43 HOK/produksi dan penggunaan tenaga paling kecil adalah pada produk keripik tahu yaitu sebesar kurang dari 0,001 HOK/produksi. Besarnya keuntungan yang diperoleh dari semua produk olahan agroindustri tesebut berkisar antara Rp4.446,38 - Rp24.705,86 dengan tingkat keuntungan antara 84,94 sampai 99,93 persen Keuntungan ini merupakan nilai tambah bersih serta merupakan imbalan bagi agroindustri.

Besarnya keuntungan yang diperoleh dari semua produk olahan pada agroindustri tesebut berkisar antara Rp4.446,38 - Rp24.705,86 dengan tingkat keuntungan antara 84,94 - 99,93 persen. Keuntungan ini merupakan nilai tambah bersih serta merupakan imbalan bagi agroindustri tersebut. Berdasarkan hasil analisis nilai tambah, diperoleh marjin keuntungan kotor dari proses pengolahan. Besarnya marjin keuntungan kotor diperoleh dari nilai produk dikurangi dengan harga bahan baku.

Berdasarkan Tabel 4, hasil perhitungan yang diperoleh nilai marjin pada setiap produk olahan pada Agroindustri Tahu Ibu Lis berkisar mulai dari Rp5.142,86 - Rp27.060 dari setiap satu kg bahan baku yang diolah. Berdasarkan marjin keuntungan kotor tersebut diketahui distribusi untuk faktorfaktor produksi seperti tenaga kerja, sumbangan input lain serta keuntungan bersih dari agroindustri.

Berdasarkan kriteria penilaian nilai tambah, yaitu jika NT > 0 berarti semua produk olahan di Agroindustri Tahu Ibu Lis memberikan nilai tambah (positif). Berdasarkan Tabel 4, penelitian ini menunjukkan bahwa pengolahan di Agroindustri Tahu Ibu Lis telah memberikan rasio nilai tambah terhadap bahan baku mulai dari 43,80 - 98,90 persen atau besarnya nilai tambah untuk semua produk berkisar antara Rp7.106,64 Rp24.724,01.

Hasil penelitian ini sejalan dengan penelitian Rosita, Hudoyo, dan Soelaiman (2019) yang menjelaskan bahwa nilai tambah pengrajin tahu kopong adalah Rp4.521,94 dan nilai tambah tahu cina yaitu Rp5.990,47. Penelitian ini juga sejalan dengan penelitain Saputra et al. (2016) dengan nilai tambah tahu adalah sebesar Rp8.184,04/kg dan penelitian Budiman et al. (2014) dengan nilai tambah yang diperoleh dari tahu ukuran kecil adalah sebesar Rp7.607,69/kg. Nilai tambah yang diperoleh dari tahu ukuran besar adalah sebesar Rp5.578,80/kg.. Berbeda 
dengan penelitian Gunanda dan Elida (2016) dengan hasil perhitungan nilai tambah kedelai menjadi produk tahu adalah sebesar Rp1.360/kg.

\section{KESIMPULAN}

Semua komponen pengadaan bahan baku sudah tepat karena sesuai dengan harapan sehingga dalam segi pengadaan bahan baku sudah baik. Kinerja produksi agroindustri sudah dikatakan baik karena empat dari enam indikator dalam kinerja produksi yaitu produktivitas, kualitas, kecepatan pengiriman dan kecepatan proses sudah sesuai, sedangkan indikator kapasitas pada produk tahu asin, tahu kuning, tahu sayur dan keripik tahu tidak sesuai dengan kriteria. Pada indikator fleksibilitas secara keseluruhan produk sudah baik. Agroindustri Tahu Ibu Lis memberikan nilai tambah yang positif yaitu berkisar dari Rp7.106,64 Rp24.724,01 sehingga Agroindustri Tahu Ibu Lis layak untuk diusahakan.

\section{DAFTAR PUSTAKA}

Assauri S. 1999. Manajemen Produksi dan Operasi, Edisi Revisi. LPFE-UI. Jakarta.

BPS [Badan Pusat Statistik Provinsi Lampung]. 2018. Produk Domestik Regional Bruto (PDRB) Atas Dasar Harga Berlaku Menurut Lapangan Usaha di Provinsi Lampung Tahun 2017. BPS. Bandar Lampung.

Budiman A, Yusri J dan Tuty E. 2014. Analisis efisiensi dan nilai tambah agroindustri tahu di Kota Pekanbaru. JOM Fakultas Pertanian, 1(1): 1-12. https://jom.unri.ac.id/index. php/JOMFAPERTA/article/view/2517/2450. [27 Maret 2019].

Gunanda R dan Elida S. 2016. Analisis agroindustri kedelai di Kecamatan Seberida Kabupaten Indragiri Hulu Privinsi Riau. Jurnal Agribisnis, 18(2): 100-117. https://journal.unilak.ac.id/index.ph/agr/article /view/772/555. [27 Maret 2019].

Hardjanto W. 1993. Bahan Kuliah Manajemen Agribisnis. IPB. Bogor.

Hayami Y, Kawagoe T, Morooka Y dan Siregar M. 1987. Agricultural Marketing andProcessing in Upland Java A Perspective
From A Sunda Village. CPGRT Center. Bogor.

Mantra IB. 2004. Demografi Umum. Penerbit Pustaka Pelajar. Yogyakarta.

Prasetya H dan Fitri L. 2009. Manajemen Operasi. Media Pressindo. Yogyakarta.

Render B dan Heize J. 2001. Prinsip-prinsip Manajemen Operasi. PT. Salemba Emban Patria. Jakarta.

Rosita, Hudoyo A dan Soelaiman A. 2019. Analisis usaha, nilai tambah, dan kesempatan kerja agroindustri tahu di Bandar Lampung. Jurnal Ilmu Ilmu Agribisnis, 7(2): 211-218. http://jurnal.fp.unila.ac.id/index.php/JIA/article/do wnload/3383/2584. [27 Maret 2019].

Sagala IC, Affandi MI dan Ibnu M. 2013. Kinerja usaha agroindustri kelanting di Desa Karang Anyar Kecamatan Gedongtataan Kabupaten Pesawaran. Jurnal Ilmu Ilmu Agribisnis, 1(1): 60-65. http://jurnal.fp. unila.ac.id/index.php/JIA/article/view/132. Maret 2019].

Saputra A, Maharani E dan Muwardi D. 2016. Analisis usaha agroindustri tahu. JOM Fakultas Pertanian Ur, 4 (2): 198-205. https://jom.unri.ac.id/index.php/JOMFAPERTA/ar ticle/view/11876/11523. [27 Maret 2019].

Sari IRM, Zakaria WA dan Affandi MI. 2015. Kinerja produksi dan nilai tambah agroindustri emping melinjo di Kota Bandar Lampung. Jurnal Ilmu Ilmu Agribisnis, 3(1): 18-25.

https://media.neliti.com/media/publications/13321ID-kinerja-produksi-dan-nilai-tambahagroindustri-emping-melinjo-di-kota-bandarlam.pdf. [27 Maret 2019].

Shafira F, Lestari DAH dan Affandi MI. 2017. Analisis keragaan agroindustri tahu kulit di Kelurahan Gunung Sulah Kecamatan Way Halim Kota Bandar Lampung. Jurnal Ilmu Ilmu Agribisnis, 6(3): 279-287. http://jurnal.fp.unila.ac.id/index.php

/JIA/article/view/3025/2414. [27 Maret 2019].

SNI [Standar Nasional Indonesia]. 1995. Standar Nasional Indonesia Untuk Kedelai. Dewan Standarisasi Nasional. Jakarta.

Soekartawi. 2010. Agribisnis: Teori dan Aplikasinya. Rajawali Press. Jakarta. 